\title{
PEMANFAATAN LIMBAH KULIT KOPI SEBAGAI UPAYA PEMBERDAYAAN KELOMPOK WANITA TANI RAFFLESIA DI DESA KUNGKAI BARU KECAMATAN AIR PERIUKAN KABUPATEN SELUMA
}

\author{
Rita Feni $^{1}$, Edi Marwan ${ }^{1}$, Fithri Mufriantie ${ }^{1}$ \\ ${ }^{1)}$ Dosen Prodi Agribisnis Fakultas Pertanian dan Peternakan UMB \\ Alamat : Jl. Bali Kampus 1 UMB Bengkulu \\ Email: ritafeniafif@gmail.com
}

\begin{abstract}
ABSTRAK
Pengabdian masyarakat ini dilaksanakan di Desa Kungkai Baru Kecamatan Air Periukan Kabupaten Seluma. Materi kegiatan ini adalah pemanfaatan limbah kulit kopi, dimana limbah kulit kopi dapat dimanfaatkan untuk pakan ternak, kerajinan tangan dan pupuk kompos yang memiliki nilai ekonomis yang tinggi.. Sasaran khalayak dari kegiatan pengabdian ini adalah Kelompok Wanita Tani Rafflesia di Desa Kungkai Baru Kecamatan Air Periukan Kabupaten Seluma sebanyak 32 orang. Manfaat dari Kegiatan pengabdian masyarakat (1) Meningkatkan pengetahuan dan keterampilan ibu-ibu anggota kelompok wanita tani dalam pemanfaatan limbah kulit kopi (2) Menambah wawasan ibu-ibu anggota kelompok wanita tani untuk membuka peluang usaha home industri pembuatan kerajinan tangan boneka dari kulit kopi. Metode yang digunakan dalam pengabdian masyarakat ini adalah penyuluhan dan demonstrasi dengan beberapa tahap kegiatan meliputi kegiatan persiapan atau pra pengbdian berupa koordinasi dan penjelasan mengenai kegiatan, tahap pelaksanaan dan tahap evaluasi kegiatan. Kegiatan ini dilakukan satu kali dalam rangkaian kegiatan pengabdian berupa penyuluhan tentang pemanfaatan limbah kulit kopi dan demonstrasi pembuatan kerajinan tangan boneka dari kulit kopi. Hasil dari kegiatan pengabdian pada masyarakat ini, antara lain (1) ibu-ibu anggota kelompok wanita di desa Kungkai Baru sangat antusias mengikuti seluruh tahapan kegiatan pengabdian ini (2) Meningkatnya pengetahuan dan keterampilan ibu-ibu anggota kelompok wanita tani dalam pembuatan kerajinan tangan dari limbah kulit kopi (3) terbukanya wawasan dan pemikiran ibu-ibu anggota kelompok wanita tani tentang manfaat dari limbah kulit kopi sebagai peluang usaha baru
\end{abstract}

\section{Kata kunci : limbah kulit kopi, kelompok wanita tani}

\section{PENDAHULUAN}

\subsection{Analisis Situasi}

Desa Kungkai Baru Kecamatan Air periukan Kabupaten Seluma mempunyai potensi untuk pengembangan sektor pertanian, dimana seperti penduduk yang menempati kawasan pedesaan umumnya memiliki mata pencaharian yang berhubungan dengan pemanfaatan alam, seperti pertanian, perkebunan, dan peternakan.

Kelompok Wanita Tani Desa Kungkai Baru merupakan suatu wadah ibu-ibu di desa tersebut untuk secara bersama-sama melakukan kegiatan usahatani dan kegiatan kewanitaan lainnya seperti usaha home industri rumah tangga yang dapat digunakan untuk menambah penghasilan keluarga. 
Kegiatan pengabdian masyarakat ini merupakan kegiatan yang diperlukan untuk menambah wawasan pengetahuan dan keterampilan para pelaku ekonomi di pedesaan termasuk didalamnya adalah kelompok wanita tani ini.

Pemanfaatan kulit biji kopi belum banyak diketahui oleh masayarakat pedesaan termasuk Kelompok wanita tani di Desa Kungkai Baru. Selama ini mereka beranggapan bahwa kulit biji kopi hanya merupakan limbah yang tidak terpakai dan tidak ada nilai ekonomisnya.

Oleh karena itu perlu adanya penambahan wawasan pengetahuan dan keterampilan ibu-ibu di kelompok wanita tani ini maka dilakukanlah pengabdian masyarakat dengan judul pemanfaatan kulit biji kopi ini.

\section{I.2. Permasalahan Mitra}

Selama ini masyarakat desa Kungkai Baru hanya mengetahui fungsi dari kulit kopi sebagai pelindung buah dan biji kopi. Biasanya kulit buah kopi hanya dibuang begitu saja sebagai limbah. Masyarakat belum mengetahui limbah kulit biji kopi dpat diolah dan dimanfaatkan untuk pakan ternak, kerajinan tangan dan pupuk kompos yang memiliki nilai ekonomis yang tinggi.

\subsection{Manfaat Pengabdian}

1. Meningkatkan pengetahuan dan keterampilan ibu-ibu anggota kelompok wanita tani di Desa Kungkai Baru dalam pemanfaatan limbah kulit kopi

2. Menambah wawasan ibu-ibu anggota kelompok wanita tani di Desa Kungkai Baru untuk membuka peluang usaha home industri pembuatan kerajinan tangan dari kulit kopi.

\section{TARGET DAN LUARAN}

\subsection{Target}

1. Peningkatan pemahaman masyarakat tentang pemanfaatan kulit biji kopi

2. Peningkatan pemahaman masyarakat tentang peluang usaha home industri pembuatan kerajinan tangan dari kulit kopi.

\subsection{Luaran}

1. Pemberdayaan ibu-ibu petani melalui kegiatan pengabdian masyarakat berupa penyuluhan dan demonstrasi pemanfaatan kulit biji kopi.

2. Produk kerajinan tangan dari kulit kopi sebagai peluang usaha baru

\section{METODE PELAKSANAAN}

\subsection{Solusi}

Solusi yang ditawarkan adalah penyuluhan dan Demonstrasi. Penyuluhan tentang pemanfaatan kulit biji kopi akan meningkatkan pemahaman tentang manfaat tambahan dari buah kopi kepada masyarakat desa mitra. Sedangkan Demonstrasi adalah suatu metode penyuluhan kepada masyarakat, dengan cara melakukan praktek langsung, agar masyarakat bisa melihat dan membuktikan terhadap objek yang didemontrasikan, dalam hal ini adalah pemanfaatan kulit biji kopi untuk kerajinan tangan yaitu boneka dari kulit kopi.

\subsection{Bentuk Kegiatan}

Pelaksanaan Pengabdian Pada Masyarakat ini dilaksanakan dengan tahapan sebagai berikut :

\section{Tahap Persiapan}

1. Koordinasi pelaksanaan program antara tim dengan mitra

2. Melakukan persiapan materi penyuluhan

3. Melakukan persiapan demonstrasi 
 \\ Ournate}

\section{Tahap Pelaksanaan}

Kegiatan yang akan dilaksanakan pada tahap ini adalah:

1. Penyuluhan

$\checkmark$ Melakukan penyuluhan kepada masyarakat desa mitra tentang pemanfaatan kulit kopi

$\checkmark$ Melakukan diskusi atau tanya jawab mengenai materi penyuluhan

2. Demontrasi kerajinan tangan pembuatan boneka dari kulit kopi

\section{Tahap Evaluasi}

Pada tahap ini akan dilaksanakan evaluasi terhadap pelaksanaan kegiatan PKM pada mitra. Pendampingan dan penilaian atas capaian program yang telah dilaksanakan terhadap mitra.

\section{HASIL KEGIATAN}

\subsection{Kegiatan Pra}

Tahap ini merupakan tahap menjelaskan dan koordinasi pelaksanaan program selama dijalankan antara tim pengusul, mitra dan pada tahap ini dilakukan penjelasan-penjelasan yang berhubungan dengan pelaksanaan program. seperti penyuluhan yang menjelaskan tentang manfaat limbah kulit kopi. Tahap pelaksanaan, pelaksanaan program sesuai dengan kesepakatan bersama antara tim pengusul dan Kelompok Wanita Tani Desa Kungkai Baru . Pada tahapan ini dihadiri oleh perwakilan dari Kelompok Wanita Tani. Dalam penjelasan ini dilakukan diskusi untuk kelancaran kegiatan baik penyuluhan dan pembuatan demonstrasi pembuatan kerajinan tangan.

\subsection{Kegiatan Penyuluhan}

Kegiatan penyuluhan dipusatkan di balai desa Kungkai Baru, dihadiri oleh Ibu-ibu kelompok tani mitra.

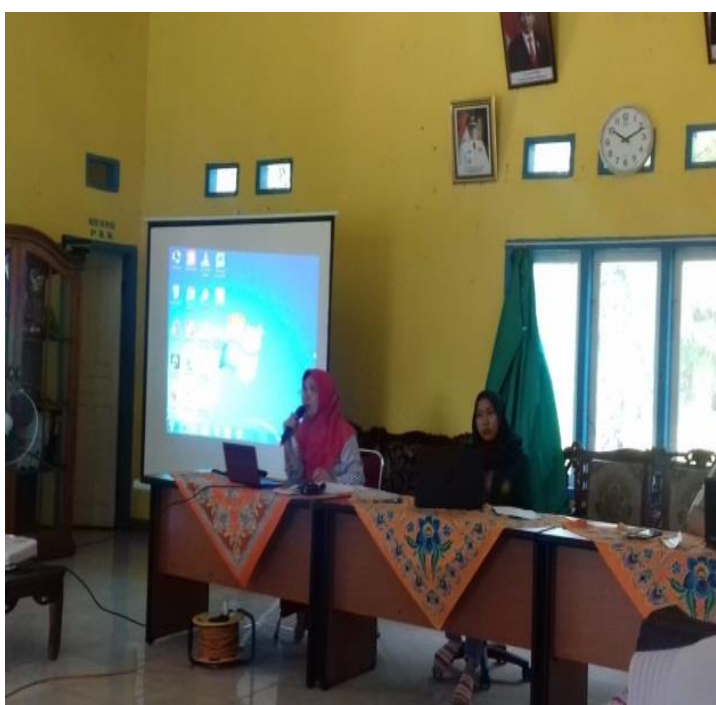

Gambar 1. Tim pengabdian memberikan materi penyuluhan

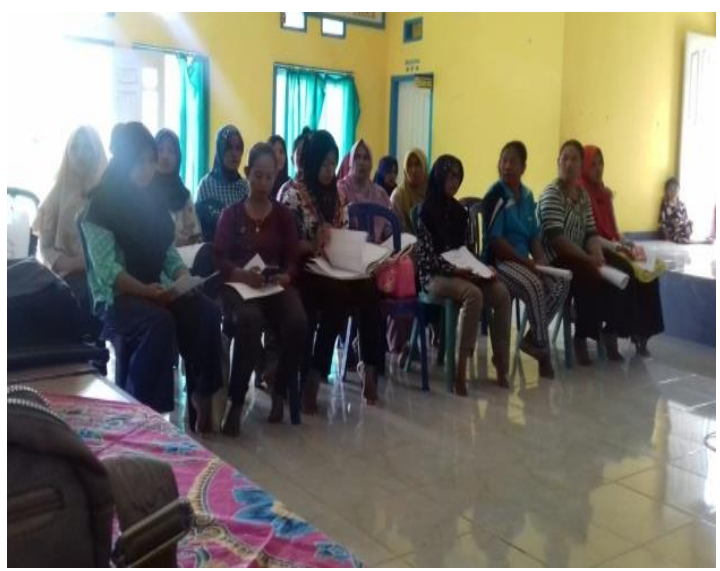

Gambar 2. Ibu-ibu kelompok wanita tani mitra

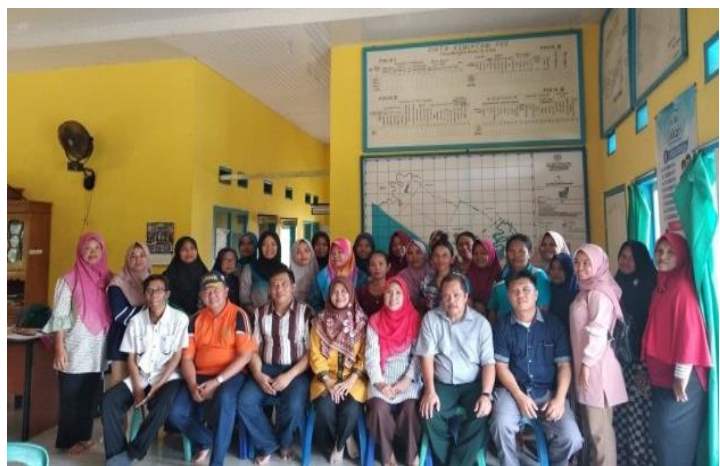

Gambar 3. Tim pemngabdian dan kelompok wanitatani mitra 


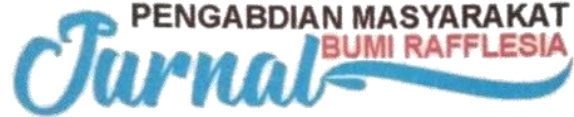

Adapun materi Penyuluhan meliputi :

Di Indonesia perkebunan kopi terdiri dari perkebunan rakyat dan perkebunan industri. Kopi merupakan salah satu komoditas yang sangat menjanjikan, karena kopi Indonesia sangat terkenal di seluruh dunia. Bahkan menurut Ditjen Perkebunan, Kementan, bahwa ekspor kopi ditahun 2016 mencapai 267.058 ton atau senilai 650 juta US Dolar. Ini membuktikan kopi menjadi salah satu komoditas unggulan.

Dengan makin berkembangnya pengolahan kopi baik skala kecil atau skala industri tentunya akan menghasilkan hasil sampingan dari pengolahan kopi tersebut yaitu salah satunya adalah limbah kulit kopi. Dari pengolahan tersebut akan menghasilkan $\pm 65 \%$ biji kopi dan $\pm 35 \%$ limbah kulit kopi yang mana limbah kulit kopi tersebut masih bisa dimanfaatkan salah satunya menjadi alternatif pakan ternak. Kandungan dalam kulit kopi sendiri memiliki kandungan nutrisi sebagai berikut CP 9,94 \%, SK 18,17\%, Lemak 1,97\%, Abu $11,28 \%$, Ca 0,68 \%, P 0,20\%, GE 3306 Kkal dan TDN 50,6 \% (Budiari, 2009).

\section{PEMANFAATAN KULIT KOPI UNTUK PAKAN TERNAK}

Peningkatan kualitas pakan dapat dilakukan melalui fermentasi. Bahan pakan yang difermentasi menggunakan limbah perkebunan dapat menggantikan hijauan pada musim kemarau. Limbah perkebunan yang tidak dimanfaatkan dapat menjadi pakan alternatif salah satunya adalah kulit kopi.

Kopi termasuk tanaman yang menghasilkan limbah hasil sampingan yang cukup besar dari hasil pengolahan. Limbah sampingan tersebut berupa kulit kopi yang jumlahnya berkisar antara 50-60 \% dari hasil panen. Limbah kulit kopi belum dimanfaatkan peternak secara optimal.
Padahal kulit kopi bisa dimanfaatkan sebagai pakan karena kulit kopi mempunyai kecernaan protein sebesar $65 \%$ dan 51,4\% untuk kulit biji.

Kulit buah kopi cukup potensial untuk digunakan sebagai bahan pakan ternak ruminansia baik itu ruminansia kecil maupun ruminansia besar. Kandungan nutrisi kulit kopi non fermentasi seperti protein kasar sebesar $8,49 \%$. Kulit kopi yang diberikan langsung dalam bentuk basah, kadar air yang cukup tinggi sehingga mudah rusak dan kurang disukai ternak.

Namun selain itu tingginya kandungan serat kasar dan adanya kandungan tanin, kafein dan lignin pada kulit kopi non fermentasi yang dapat mengganggu pencernaan ternak jika diberikan dalam jumlah banyak. Salah satu cara untuk meminimalkan faktor pembatas tersebut, kulit kopi diolah terlebih dahulu sebelum diberikan kepada ternak, melalui teknologi fermentasi.

Limbah kulit kopi difermentasi terlebih dahulu untuk meningkatkan kandungan nutrisinya. Fermentasi kulit kopi biasanya menggunakan larutan Aspergillus Niger. Cara pembuatannya adalah campurkan air dengan gula pasir, NPK, Urea, dan Aspergillus Niger kemudian campuran tersebut diinkubasi dan diaerasi selama 24-36 jam dan larutan tersebut siap digunakan. Kemudian limbah kulit kopi dicampur dengan larutan tersebut dengan membuat lapisan-lapisan campuran tersebut dan letakkan di tempat yang teduh dari hujan dan sinar matahari langsung. Diamkan selama 5-6 hari untuk proses fermentasi dan setelah 5-6 hari limbah kulit kopi yang telah terfermentasi dikeringkan kemudian giling sesuai kebutuhan dan limbah kulit kopi terfermentasi siap digunakan sebagai pakan ternak.

Salah satu kendala pemanfaatan kulit kopi sebagai pakan ternak adalah kandungan serat kasarnya yang tinggi $(33,14 \%)$, sehingga tingkat kecernaannya sangat rendah. Dengan proses 
amoniasi, tingkat kecernaan kulit kopi bisa ditingkatkan. Bukan hanya itu, amoniasi kulit kopi juga dapat meningkatkan kadar protein serta menghilangkan aflatoksin.

Bahan yang digunakan dalam pembuatan amoniasi kulit kopi adalah 20 $\mathrm{kg}$ kulit kopi kering udara, $1 \mathrm{~kg}$ urea, dan 14 liter air. Adapun peranti yang dibutuhkan meliputi timbangan, gelas ukur, terpal plastik, kantong plastik (disesuaikan dengan jumlah bahan), ember, dan pengaduk.

Cara pembuatannya, kulit kopi dihamparkan pada terpal / lembaran plastik berukuran 180 x $200 \mathrm{~cm} 2$. Masukkan 14 liter air ke dalam ember, dan masukkan pula $1 \mathrm{~kg}$ urea ke dalamnya. Aduk terus sampai urea larut. Siramkan larutan urea ke kulit kopi secara merata, kemudian dibolakbalik sampai seluruh bagian kulit basah oleh larutan tersebut. Masukkan kulit kopi ke dalam plastik kantong (90x $100 \mathrm{~cm})$ secara rangkap, kemudian dipadatkan, dan diikat erat-erat.

Pastikan tak ada kebocoran pada kantong plastik. Setelah empat minggu, amoniasi kulit kopi sudah dapat dibuka. Amoniasi diangin-anginkan selama 1-2 hari, sampai bau menyengat amoniak hilang. Sekarang, hasil amoniasi bisa digunakan sebagai pakan sapi atau domba.

Kulit kopi yang telah diamonasi mempunyai kandungan protein $17,88 \%$, kecernaan $50 \%$ (semula $40 \%$ ), VFA 143 $\mathrm{mM}$ (semula $102 \mathrm{mM}$ ) dan NH3 12,04 mM (semula 4,8 mM).

Struktur dinding sel kulit kopi juga menjadi lebih amorf dan tidak berdebu, sehingga lebih mudah ditangani. Dalam keadaan tertutup (plastik belum dibuka / dibongkar), bahan pakan yang diamoniasi dapat tahan lama.

\section{PEMANFAATAN KULIT KOPI UNTUK KERAJINAN TANGAN}

Kulit kopi dapat juga dipakai
untuk membuat beraneka ragam kerajinan tangan, dalam pengabdian masyarakat ini akan dibuat boneka dari kulit kopi. Dimana boneka dari kulit kopi dapat menjadi suatu peluang usaha yang cukup potensial untuk menambah penghasilan keluarga bila diusahakan secara sunguh-sungguh menjadi sebuah bisnis homeindustri.

\section{PEMANFAATAN KULIT KOPI UNTUK KOMPOS}

Kompos merupakan hasil fermentasi (dekomposisi) dari bahan-bahan organik seperti tanaman, hewan, atau limbah organik lainnya. Kompos yang digunakan sebagai pupuk disebut pupuk organik karena penyusunannya terdiri dari bahan-bahan organik. Bahan-bahan organik yang umum dimanfaatkan sebagai kompos adalah : limbah pertanian dan residunya, limbah ternak dan residunya, pupuk hijau, tanaman air, limbah industri padat dan cair, limbah rumah tangga dan sampah.

Kompos berasal dari sisa bahan organik, baik dari tanaman, hewan, maupun limbah organik yang telah mengalami dekomposisi atau fermentasi. Kompos dan humus merupakan pupuk organik dari hasil pelapukan jaringan atau bahan-bahan tanaman atau limbah organik. Penampilan atau sifat fisik kompos dan humus tidak berbeda. Perbedaannya hanya terletak proses terbentuknya. Kompos terbentuk dengan adanya campurtangan manusia, sedangkan humus terbentuk secara alami.

Bahan-bahan yang diperlukan untuk pengolahan limbah kulit kopi menjadi komps cukup mudah diperoleh, yaitu kulit kopi kering dan basah masingmasing $5 \mathrm{~kg}$, air, pupuk kandang, larutan EM-4, dan tetes tebu. Adapun langkahlangkahnya juga cukup sederhana dan tidak sulit dilakukan. Pertama, siapkan limbah kulit kopi kering dan basah masing-masing $5 \mathrm{~kg}$. Kemudian limbah 
kullit kopi dicacah menjadi kecil-kecil (untuk kulit basah boleh ditumbuk menggunakan lesung). Kedua, tambahkan pupuk kandang secukupnya. Ketiga, tambahkan $100 \mathrm{ml}$ larutan EM4 dan 2 sdm tetes tebu yang sudah dilarutkan ke dalam limbah kulit kopi dan diaduk-aduk agar bahan tercampur rata. Selanjutnya bahan-bahan tersebut dimasukkan ke dalam bak dan ditutup rapat dengan plastik selama satu minggu agar terjadi fermentasi sembari melakukan homogenisasi biomassa dengan pengadukan. Kompos sudah dapat digunakan setelah fermentasi matang.

Dengan adanya kajian dan bahasan tentang manfaat dan kegunaan lain dari sisa pengolahan bubuk kopi yang berupa kulit kopi ini, masyarakat dapat mengolah bahan yang dianggap limbah tersebut menjadi bahan yang lebih bermanfaat sehingga bisa menjadi penambah penghasilan keluarga selain produk utama bubuk kopi.

\subsection{Demonstrasi Kerajinan Kulit Kopi}

Tim pelaksanaan pengabdian dibantu dengan mahasiswa dari program studi Agribisnis Fakultas Pertanian Universitas Muhammadiyah Bengkulu membuat demonstrasi kerajinan tangan yaitu membuat boneka dari kulit kopi.

Alat dan bahan yang dipakai adalah sebagai berikut :

Alat dan Bahan

\begin{tabular}{|l|l|}
\hline Alat & Bahan \\
\hline Centong Kayu & Dempul Kayu \\
Terpal & Lem Kayu \\
Plastik UV & Cat dasar \\
Tripleks 4 mm & Limbah kulit kopi \\
Pisau & Cat Warna \\
Kuas cat & Kotak mika \\
Alat Lem tembak & Asesoris boneka \\
Cetakan & Tiner \\
Gunting & Lem lilin Amplas \\
Sarung Tangan & Kain flanel \\
Ember & \\
\hline
\end{tabular}

Sedangkan cara pembuatannya adalah sebagai berikut :

\section{Tahap Pertama}

1. Tahap yang paling awal adalah keringkan kulit kopi dengan cara dijemur.

2. Kulit kopi yang sudah kering selanjutnya campurkan dengan lem kayu kedalam ember.

3. Setelah lem dan limbah kulit kopi menyatu selanjutnya masukkan limbah kulit kopi ke dalam pencetakan (berupa boneka plastik)

4. Proses terakhir seletah pembentukan adalah penjemuran, jemur dibawah materi benar kering.

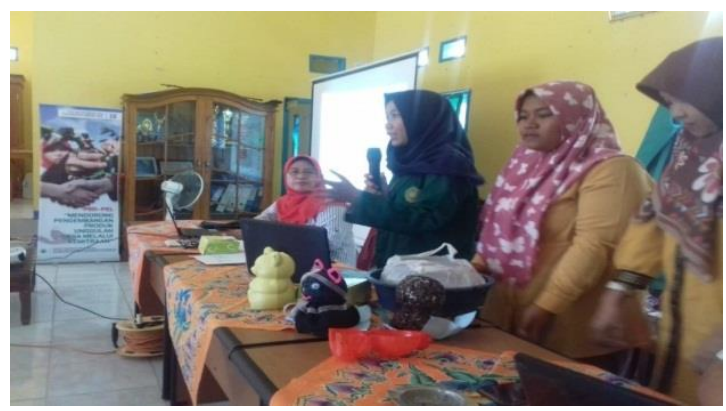

Gambar 4. Tim pengabdian memberikan demonstrasi kerajinan dari kulit kopi

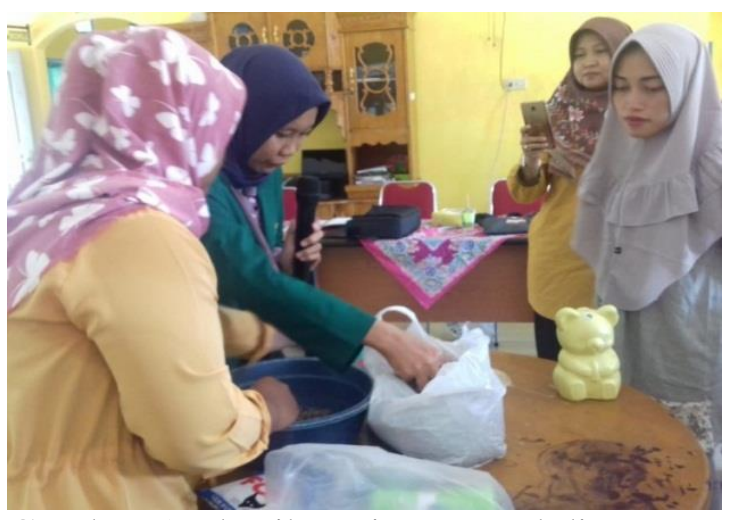

Gambar 5. Ibu-ibu mitra pengabdian memperhatikan demonstrasi

\section{Tahap Kedua}

1. Siapkan semua bahan dan alat yang sudah tersedia, selanjutnya amplas boneka yang sudah terbentuk dari limbah kulit kopi menggunakan amplas, 
tujuannya agar boneka lebih terlihat halus.

2. Setelah boneka diamplas cat boneka menggunakan cat dasar dengan kuas cat, tujuannya agar pori-pori dari boneka limbah kulit kopi tertutup.

3. Setelah cat dasar kering selanjutnya lapisi dengan cat warna sesuai dengan jenis atau bentuk.

4. Selanjutnya setelah cat kering bentuk dan hiasi boneka menggunakan kain flanel dan aksesoris yang mendukung.

5. Tahap finishing dari proses pembuatan boneka adalah bungkus boneka dengan plastik boneka.

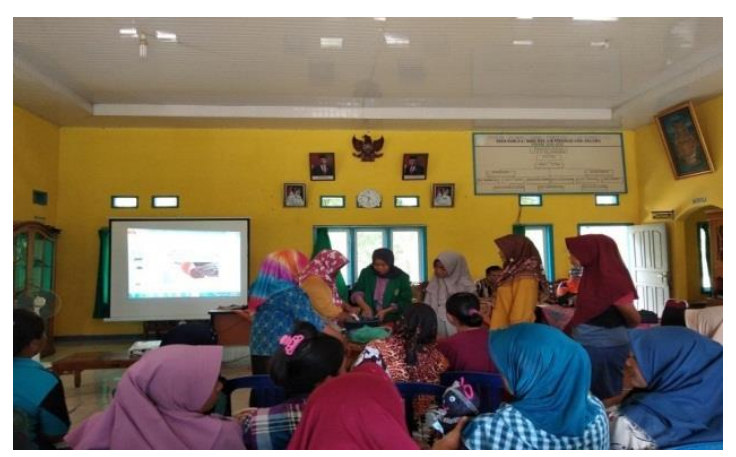

Gambar 6. Tahap akhir dari demonstrasi

\subsection{Evaluasi}

Di akhir kegiatan ini dilakukan evaluasi untuk mengetahui tentang kegiatan pengabdian dan tanggapan dari mitra terhadap pelaksana pengabdian kepada masyarakat yang dilakukan oleh Tim Pengabdian Universitas Muhammadiyah Bengkulu.

Tanggapan mitra dengan adanya kegiatan ini sangat antusias mengingat kegiatan seperti ini masih sedikit dilakukan dan mitra meminta untuk kembali dikutsertakan dalam pengabdian masyarakat berikutnya.

\section{KESIMPULAN DAN SARAN}

\subsection{Kesimpulan}

1. Peningkatan pengetahuan dan keterampilan ibu-ibu anggota kelompok wanita tani dalam pembuatan kerajinan tangan dari limbah kulit kopi

2. Ibu-ibu anggota kelompok wanita di desa Kungkai Baru sangat antusias mengikuti seluruh tahapan kegiatan pengabdian ini

3. Terbukanya wawasan dan pemikiran ibu-ibu anggota kelompok wanita tani tentang manfaat dari limbah kulit kopi sebagai peluang usaha baru

\subsection{Saran}

Perlu adanya keikutsertaan peran dari pemerintah khususnya instansi terkait untuk peningkatan pengetahuan masyarakat desa melalui penyuluhan, pelatihan ataupun demonstrasi.

\section{DAFTAR PUSTAKA}

Anonim.http://duniagalery.blogspot.com/20 15/06/makalahpupuk-kompos-darilimbah-kopi.html. Pupuk Kompos dari Limbah Kopi. Diakses 17 Desember 2019.

Kementerian Pertanian Republik Indonesia. https://www.pertanian.go.id/home/? show $=$ news\&act $=$ view\&id=3198 Limbah Kulit Kopi Sebagai Alternatif Pakan Ternak.. Diakses 16 Desember 2019

Anonim.https://www.sapibagus.com/manfa at-kulit-kopi-untuk-pakan-ternak/ Manfaat kulit kopi untuk pakan ternak. Diakses 16 Deseber 2019.

Anonim.https://coffeeland.co.id/pemanfaata n-limbah-kulit-kopi/Pemanfaatan Limbah Kulit Kopi.Diakses 17 Desember 2019.

Anonim.https://kampoengternak.or.id/kopiuntuk-ternak/ Kopi Untuk Ternak. Diakses 16 Desember 2019. 